\title{
Commentary: Crisis as Opportunity? Europe at the Crossroads
}

\author{
Monika Eigmüller (monika.eigmueller@uni-flensburg.de)
}

Flensburg University, Germany

The European Union is in crisis. We are witnessing the multiple failures of European states on a daily basis. The way in which, for example, very high numbers of refugees are treated is indicative of institutional failures that should have been dealt with a long time ago.

At the heart of the European idea is the realisation of a free internal market, and so the removal of internal borders within the EU. The integration project presupposes joint action to secure the external borders and to establish common procedures for managing crossing points, asylum applications, and migratory movements. For quite some time this has ceased to be treated as a common task, but rather as something that could be delegated by the central states to those on the southern and eastern periphery. In addition, neighbouring states are increasingly drawn into the European border regime: in exchange for the partial opening up of frontiers to their own populations, nearly all of them have now signed so-called repatriation agreements with the EU. This in turn provides a model for the current negotiations between Turkey and the EU in which the former is to assume some responsibility for EU border security.

This system, known as the "Dublin" system, decrees that refugees must apply for asylum in their country of first arrival, seeking to prevent unwanted migration to the EU states. This was also a condition for the removal of internal borders, and so a core element of the integration project as a whole. Without "Dublin" no "Schengen", and without "Schengen" no EU - so the logic went.

Recent events have raised serious questions about this system; free movement across internal borders has been repeatedly blocked, with the high number of refugees cited as the cause. Even the central states have eventually come to realise that the imposition of "Dublin" is no longer viable; instead, they now seek to develop a quota system.

However, there has been much hesitation in addressing the underlying problem. For all the obsession with detail that has always characterised the creation of the "European Border" as a common institution, the need for a common, comprehensive European policy for asylum and migration was completely overlooked. Lacking any agreement on the manner in which migration into the member states should be managed, the project to create a common and secure border was doomed from the beginning. The Schengen system worked only for so long as the external borders did actually prevent refugees gaining access to the Union. Since the beginning of the Arab Spring, and the outbreak of civil war in Syria and Afghanistan, there has been enormous pressure on the external borders of Europe, and the system was bound to collapse.

All the same, the current crisis contains a unique opportunity: to put an end to the Dublin protocol and initiate a humane asylum policy. However, this would require united action 
on the part of the member states of the Union; something which is all the more improbable, given that the crisis has exposed the fundamental differences between EU states - not only in respect of language and culture, but above all in respect of basic values such as the right to asylum. The diagnosis is, however, crystal clear: the current problem is not an excess of common co-ordination and political management within the EU, but a deficiency.

A solution to the problem can only be found in thoroughgoing reform of the EU, in particular, comprehensive democratic legitimation of its institutions. Only if these are placed on a proper democratic footing will it be possible to provide an effective response to the automatic reflex of European nation states: to withdraw from Europe at just that point where transnational solidarity is needed. This is particularity true of the European Commission, whose proposals, in a time of national self-interest, echo emptily because of its lack of democratic legitimacy, given its absence from established domains of democratic competition.

There is still no prospect of democratic solidarity between the member states of the European Union - a solidarity that is not only self-interested but, as Émile Durkheim would have put it, morally supportable. The European project is once more at a crossroads: whether the crisis will prompt further integration, not only of markets but also of societies, is yet to be seen. For the refugees and for European society - and so for the European project itself - there is in the long run no alternative.

Translated by Keith Tribe

Further Reading

Georg Vobruba, Die Dynamik Europas, Wiesbaden, VS-Verlag 2007.

Monika Eigmüller, Georg Vobruba, "Selektive Grenzöffnung im Rahmen der Europäischen Nachbarschaftspolitik", in Martin Möllers, Robert van Ooyen (eds.), Migration, Integration und Europäische Grenzpolitik. Sonderheft des Jahrbuchs für Öffentliche Sicherheit, 2010 pp. 14-17. 